\title{
The use of utility function for optimization of thermoforming
}

\author{
Emil Sasimowski ${ }^{1)}$ \\ DOI: dx.doi.org/10.14314/polimery.2018.11.9
}

\begin{abstract}
The paper describes a utility function - based method for optimization of a thermoforming process for producing finished parts made of polystyrene sheet by vacuum forming and vacuum assisted drape forming with and without pre-blow. Not only does the proposed method enable determination of optimum thermoforming conditions, it also provides information about interactions between these conditions as well as about their impact on the properties of finished parts and polymer heating time, a factor which affects efficiency of this process. The determined optimum thermoforming conditions significantly differ for thermoforming without pre-blow and thermoforming with pre-blow, which results from different ways of forming individual regions of polystyrene sheet during both processes. The employed method enables determination several optimum criteria, the number of which can be extended as desired, which is significant for practical applications of machines and devices.
\end{abstract}

Keywords: optimization, utility function, thermoforming, polystyrene.

\section{Wykorzystanie funkcji użyteczności w optymalizacji procesu termoformowania}

Streszczenie: W pracy przedstawiono metodykę optymalizacji z wykorzystaniem funkcji użyteczności na przykładzie procesu termoformowania. Optymalizacji wielokryterialnej poddano proces termoformowania kształtek z folii polistyrenowej metodą próżniowego rozciągania stemplowego, bez rozdmuchiwania wstępnego oraz z rozdmuchiwaniem wstępnym. Zaprezentowana metoda umożliwia wyznaczenie optymalnych warunków termoformowania, poszerza również wiedzę w zakresie ich wzajemnych korelacji i siły wpływu na właściwości otrzymywanych kształtek oraz czas nagrzewania folii, determinujący wydajność tego procesu. Wyznaczone optymalne wartości parametrów termoformowania $\mathrm{w}$ istotnym stopniu różnią się $\mathrm{w}$ wypadku procesu bez rozdmuchiwania wstępnego i $\mathrm{z}$ jego zastosowaniem, co jest następstwem odmiennego przebiegu rozciąganiu poszczególnych obszarów folii w obu procesach. Wykorzystana metoda pozwala na poszukiwanie optimum uwzględniającego wiele cech - kryteriów jednocześnie, które ponadto można rozszerzać w zależności od potrzeb, co ma duże znaczenie w praktycznych zastosowaniach eksploatacyjnych maszyn i urządzeń.

Słowa kluczowe: optymalizacja, funkcja użyteczności, termoformowanie, polistyren.

Previous studies on the optimization of polymer processing were only concerned with extrusion [1-4] and injection molding $[5,6]$ processes, and they were primarily based on numerical data and only rarely on experimental data [7-10]. There are no studies devoted to the problem of thermoforming optimization.

Thermoforming is widely used to manufacture products with a non-developable surface made of plastic sheet or thermoplastic polymer plates. This method is mainly used to produce disposable packaging (containers, cups, trays) as well as structural components of various devi-

\footnotetext{
1) Lublin University of Technology, Department of Technology and Polymer Processing, Nadbystrzycka 36, 20-618 Lublin, Poland.

e-mail: e.sasimowski@pollub.pl
}

ces (inside walls of refrigerators, casings, switch boards). Thermoforming consists in plasticization of a thermoplastic plate or sheet in a forming mold to generate tensile stresses that cause its plastic deformation and adherence to the mold cavity; after that, the finished part is cooled and released [11, 12]. Thermoforming has many variants which differ in aspects such as the applied stretch factor, the part of the mold in which stretching takes place and the application of pre-stretch which can also be caused by different factors [13-16]. Although this process is similar to other polymer processing methods [17-19], it requires separate studies due to its specificity. Despite the fact that the origins of thermoforming go back to the 1870s and its practical aspects have been thoroughly examined, the process is still the subject of numerous research studies [20-32] and publications for manufacturers [33-35]. 
In this paper, a thermoforming process for producing polystyrene sheet by vacuum forming and vacuum assisted drape forming with and without pre-blow is investigated. The aim of this study was to optimize the investigated thermoforming process with respect to the smallest variations in wall thickness of finished parts in their longitudinal and cross sections. Besides improving the quality of finished parts, emphasis was also put on polystyrene sheet heating time, as it has a direct impact on efficiency of this process. For this reason, the evaluation of optimum conditions of the process was based on a number of criteria. The procedure included a few steps [36, 37]. First of all, it was necessary to determine factors - independent variables which have a significant effect on dependent variables describing the process, and then, based on the equation describing relations between them, to design a model of the process. After that, it was necessary to determine values of independent variables which ensure obtaining the most desired (useful) approximated values of the dependent factors. By determining the optimum values of independent variables based on selected dependent variables, a new variable is defined, i.e., total quality. This consists in transforming approximated values of many dependent factors into a unit value of total utility. As a result, the problem is simplified to finding values of independent factors maximizing the value of total utility. For every optimized factor (criterion), a non-dimensional utility function is defined and ascribed values from the range $0-1$ describing satisfaction of the obtained value of dependent factor on a specified level. The simplest utility profile has the form of a linear function, where the most favorable value of the optimized factor was ascribed the utility function equal to 1 , the value corresponding to the middle of the optimized range was ascribed 0.5 , whereas the least desired value was made equal to 0 .

Using the defined utility functions for every optimized factor (criterion), partial utilities are determined, the geometrical mean of which is the value of total utility. Next, using the spline functions method or the least squares method, a model of total utility is designed. The model is used for predicting total utility, that is, for finding an optimum solution where independent factors have the highest total utility values.

\section{EXPERIMENTAL PART}

\section{Methodology}

Tests specimens were prepared by vacuum assisted drape forming with and without pre-blow on the PEX B-3 F test stand [38]. This test stand comes with a heater with HTS ceramic infrared radiators with a total power of $3.6 \mathrm{~kW}$ which form two zones: the external zone comprising the circumferential part of the plastic sheet subjected to heating and the internal zone corresponding to the central part of this region. The radiators are distanced from the surface of the heated plastic sheet by $130 \mathrm{~mm}$. The test stand is equipped with a vacuum pump which generates pressure of $2 \mathrm{hPa}$. The tests were performed using an MDF male mold in the shape of truncated pyramid $(340 \times 190 \mathrm{~mm}$ rectangular base, a height of $80 \mathrm{~mm}$, and a top of $300 \times 150 \mathrm{~mm}$ ) described by a depth-of-draw ratio $k$, set to 0.53 . The tests were performed on high impact polystyrene flat sheet with a thickness of $0.5 \mathrm{~mm}$ manufactured by P.P.H.U. Petroplast Ltd. The following independent variables were examined:

- heating time $(T, \mathrm{~s})$;

- temperature in external zone of the heater $\left(t_{z^{\prime}}{ }^{\circ} \mathrm{C}\right)$;

- temperature in internal zone of the heater $\left(t_{w^{\prime}}{ }^{\circ} \mathrm{C}\right)$;

- time of pre-blow $\left(T_{r}=1 \mathrm{~s}, T_{r}=0 \mathrm{~s}\right.$ without pre-blow).

Pre-blow time is a period of time when compressed air is introduced between the mold and the sheet, leading to the stretching of the sheet and the bubble formation at the same time.

Constant factors included:

- vacuum time: $6 \mathrm{~s}$;

- cooling time: $5 \mathrm{~s}$;

- duration and frequency of compressed air impulses fed for separating the workpiece from the mold: $1 \mathrm{~s}$ and $2 \mathrm{~Hz}$, respectively;

- compressed air pressure in the working unit of the test stand: $0.33 \mathrm{MPa}$.

The wall thickness of finished parts was measured with an accuracy of $0.001 \mathrm{~mm}$ by an electronic micrometer at the characteristic measuring points which are marked in Fig. 1.

Next, variations in wall thickness in a longitudinal section $\Delta g$ were calculated by determining a difference between the maximum and minimum wall thicknesses measured in this section. The variations in wall thickness in the cross section $\Delta g^{\prime}$ were calculated in a similar way.

Specimens for the tests were produced in compliance with [37], a central composite rotatable design with the star point distance $\alpha$ set to 1.6818 . The adopted design requires investing five values of independent variables defined by the coded values equal to $(-\alpha,-1,0,+1,+\alpha)$. This design enables the approximation of the second degree polynomial. In the rotatable design, the approximation

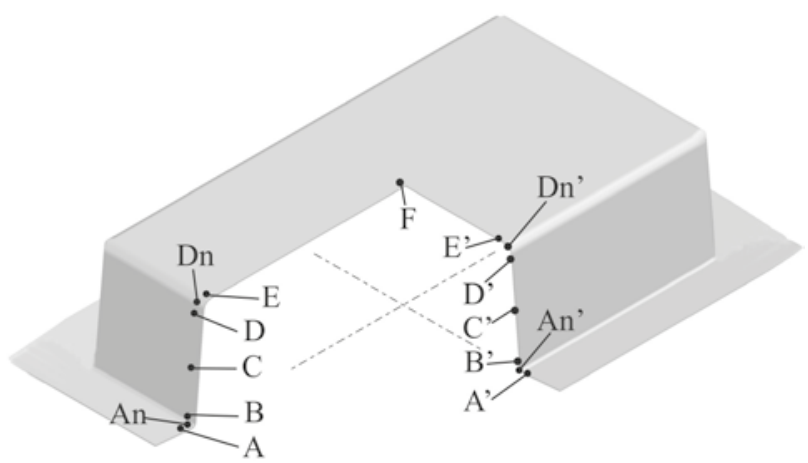

Fig. 1. Schematic design of the finished product; the measuring points of wall thickness in longitudinal section A-F and cross section $A^{\prime}-E^{\prime}$ are marked in the figure 
accuracy does not depend on the adopted values of independent variables, the variance of the dependent variable remains constant. The measurements were repeated twice, with pre-blow and without pre-blow, respectively. In the centre point, the measurements were repeated six times leading to a total set of 20 runs. The independent variables had the following ranges: $\left(t_{z}\right) \in(386$ to 454$){ }^{\circ} \mathrm{C}$, $\left(t_{w}\right) \in(386$ to 454$){ }^{\circ} \mathrm{C}$ and $(T) \in(15$ to 29$) \mathrm{s}$.

A regression analysis was performed using Statistica 13 to determine relationships between the dependent variables, i.e., variations in wall thickness of the finished part in the longitudinal section $(\Delta g)$ and cross section $\left(\Delta g^{\prime}\right)$ and the applied independent variables $t_{z^{\prime}} t_{w}$ and $T$.

The empirical model of this relationship could be approximated by a polynomial equation:

$Y=a_{0}+a_{1} t_{z}+a_{2} t_{w}+a_{3} T+a_{12} t_{z} t_{w}+a_{23} t T+$

$a_{13} t T+a_{11} t_{z}^{2}+a_{22} t_{w}^{2}+a_{33} T^{2}$

where: $Y$ - the predicted response value $(Y$ stands for $\Delta g$ or $\left.\Delta g^{\prime}\right), a_{\mathrm{n}}$ - the regression coefficients and weighting factors which are numbers calculated by the statistical program to fit the experimental data.

Three linear utility functions were defined for each optimized factor (criterion), and they included: wall thickness variations $(\Delta g)$ in longitudinal section, wall thickness variations $\left(\Delta g^{\prime}\right)$ in cross section, and heating time (T). The utility function was made equal to 1 for the most desired values of optimized factors, i.e., for the smallest variations in wall thickness in both examined sections and the shortest heating time. The least desired, i.e., the highest values of optimized factors were assigned a utility function of 0 , whereas the values corresponding to the middle of optimized ranges were made equal to 0.5 .

In Statistica 13, partial utilities were determined using the defined utility functions for every optimized factor. After that, the spline functions method was employed to obtain a total utility model which was used for finding an optimum solution.

\section{RESULTS AND DISCUSSION}

The collected measurements were used to estimate the coefficients of regression models. The empirical models of the wall thickness variations in the longitudinal section $(\Delta g)$ and in cross section $\left(\Delta g^{\prime}\right)$ for finished parts produced without pre-blow were obtained as Eq. (2) and (3).

$$
\begin{aligned}
& \Delta g=4.05956-0.009665 t_{w}+0.00001296 t_{w}{ }^{2}- \\
& 0.0123802 t_{z}+0.0000032 t_{z}{ }^{2}+0.0957118 T- \\
& 0.0008803 T^{2}+0.0000128 t_{z} t_{w}-0.000323 t_{w} T+ \\
& 0.000192 t_{z} T
\end{aligned}
$$$$
\Delta g^{\prime}=2.1077-0.002271 t_{w}+0.00002584 t_{w}{ }^{2}-
$$$$
0.009977 t+0.00002098 t_{z}^{2}+0.057694 T-
$$$$
0.0010003 T^{2}-0.00003218 t_{z} t_{w}-0.000239 t_{w} T+
$$$$
0.000242 t_{z} T
$$

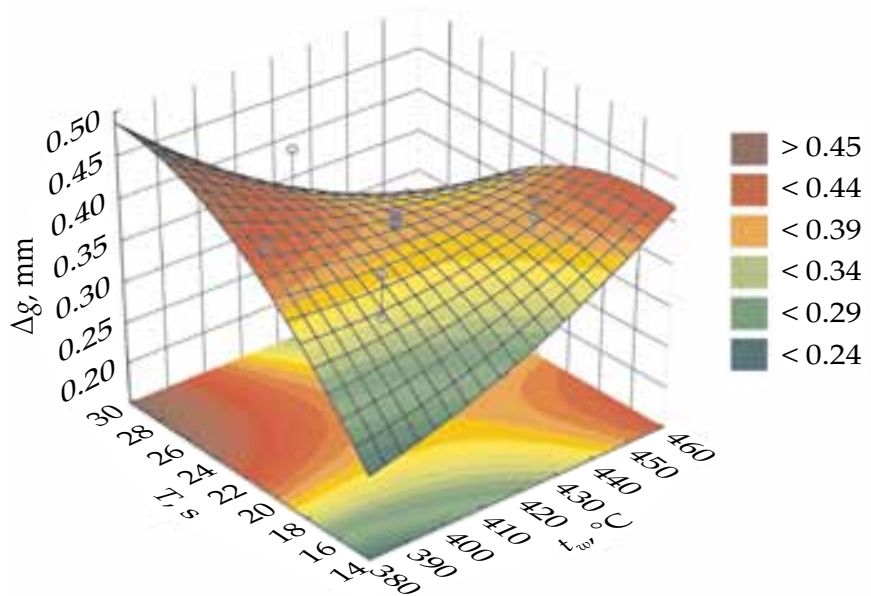

Fig. 2. Variations in wall thickness $(\Delta g)$ in the longitudinal section of finished parts produced without pre-blow versus internal zone temperature $\left(t_{w}\right)$ and heating time $(T)$ at $t_{z}=420^{\circ} \mathrm{C}$

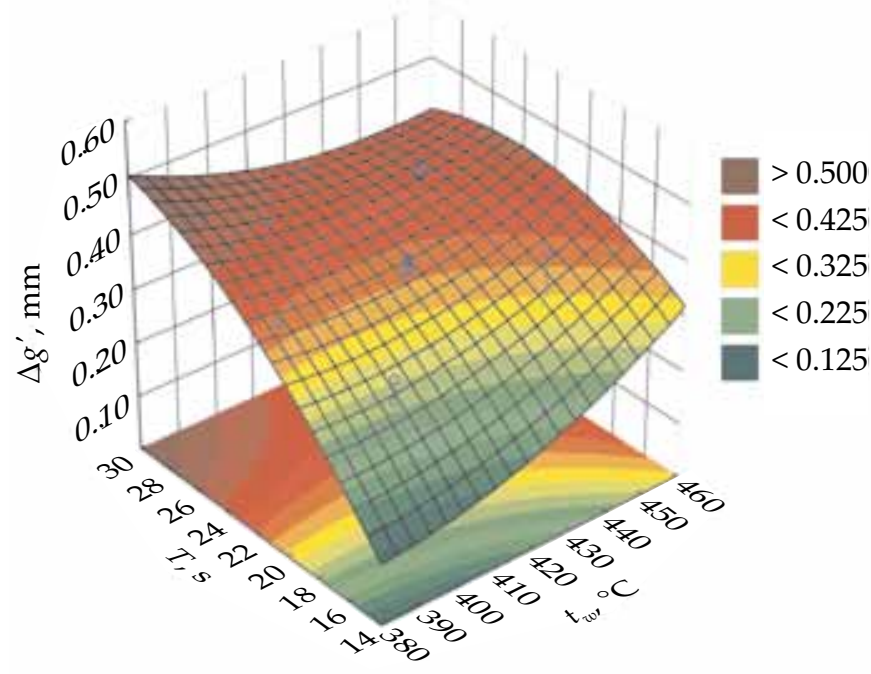

Fig. 3. Variations in wall thickness $\left(\Delta g^{\prime}\right)$ in the cross section of finished parts produced without pre-blow versus internal zone temperature $\left(t_{w}\right)$ and heating time $(T)$ at $t_{z}=420^{\circ} \mathrm{C}$

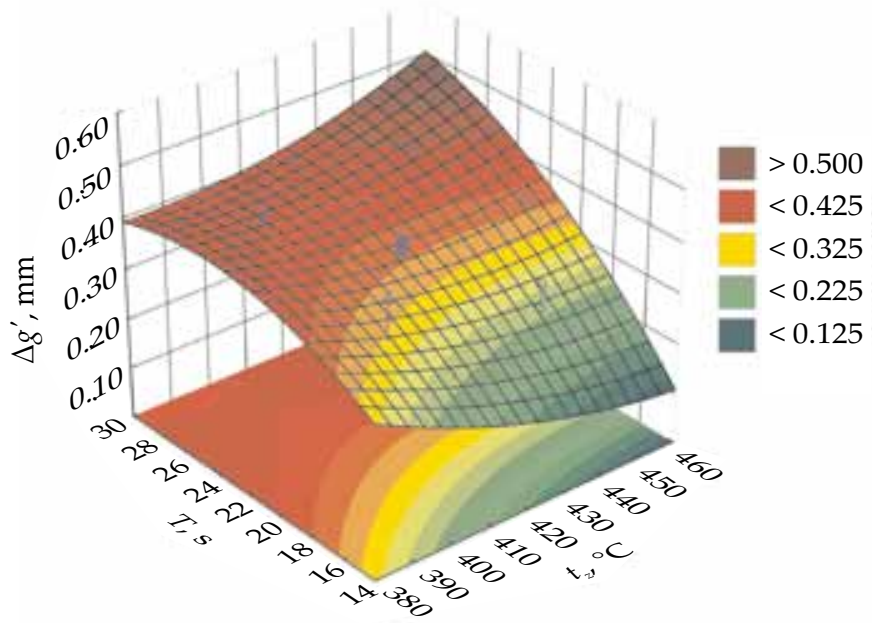

Fig. 4. Variations in wall thickness $\left(\Delta g^{\prime}\right)$ in the cross section of finished parts produced without pre-blow versus external zone temperature $\left(t_{z}\right)$ and heating time $(T)$ at $t_{w}=420^{\circ} \mathrm{C}$ 
The effect of the independent variables on the variations in wall thickness in the longitudinal and cross sections of finished parts was investigated by Pareto analysis. The results demonstrate that as far as finished parts produced without pre-blow are concerned, the wall thickness variations in the longitudinal section $(\Delta g)$ are significantly affected by interactions between the temperature in the internal zone of the heater $\left(t_{w}\right)$ and the heating time $(T)$. The variations in wall thickness in the cross section $\left(\Delta g^{\prime}\right)$ are predominantly affected by the heating time $(T)$ as well as its interactions with the internal zone temperature $\left(t_{w}\right)$ and external zone temperature $\left(t_{z}\right)$ in the heater.

The effect of the above-mentioned independent variables on the variations in wall thickness in the longitudinal section $(\Delta g)$ is shown in Fig. 2, while that on the wall thickness variations in the cross section $\left(\Delta g^{\prime}\right)$ in Figs. 3 and 4 .

The determination of partial utilities by the spline functions method led to obtaining a total utility model. The total utility of finished parts produced without pre-blow for every pair of input variables is illustrated in Fig. 5. The values of total utility marked in the diagram by different color. When the pair of parameters is represented in the diagram, the remaining factors are fixed and have optimal values. The model was used to find optimum utility by browsing through the input variables mesh nodes in the examined region. This method consists in browsing through all given combinations of input values in the mesh nodes in order to find a combination which will eventually yield optimum total response utility.

Profiles of approximated optimized factors $\left(\Delta g, \Delta g^{\prime}, T\right)$ were made comprising of a series of charts, one per each input variable, illustrating values predicted at every mesh point (Fig. 6). Diagrams were made for every factor to illustrate its profile of total response utility at every point of the input mesh at optimum current values of other factors (three diagrams at the bottom of the figure). The figure also shows the diagrams of defined linear utility functions for the optimized factors (diagrams on the right, vertical column). To give an example, the diagram in the top-left corner of the figure illustrates the relationship between the wall thickness variation $(\Delta g)$ and the temperature $t_{w}$ at constant optimal values of $t_{z}=453.64^{\circ} \mathrm{C}$ and $T=15.27 \mathrm{~s}$. The diagram in the bottom-left corner of the figure shows the relationship between the total response utility and the temperature $t_{w}$ at constant optimal values of $t_{z}$ and $T$.

The input variables: $t_{w}=403{ }^{\circ} \mathrm{C}, t_{z}=454{ }^{\circ} \mathrm{C}$ and $\mathrm{T}=15 \mathrm{~s}$, led to obtaining the approximated values $\Delta g=0.259 \mathrm{~mm}$ and $\Delta g^{\prime}=0.149 \mathrm{~mm}$. When the total utility equals 1 , it means that, on applying the above independent factors, all optimization criteria are met in thermoforming without pre-blow. In the diagram illustrating total utility versus temperatures $t_{w}$ and $t_{z}$ (Fig. 5), the region around the optimum is quite extensive, which means that deviations up to even several degrees from the determined optimum values should not lead to a decrease in utility.
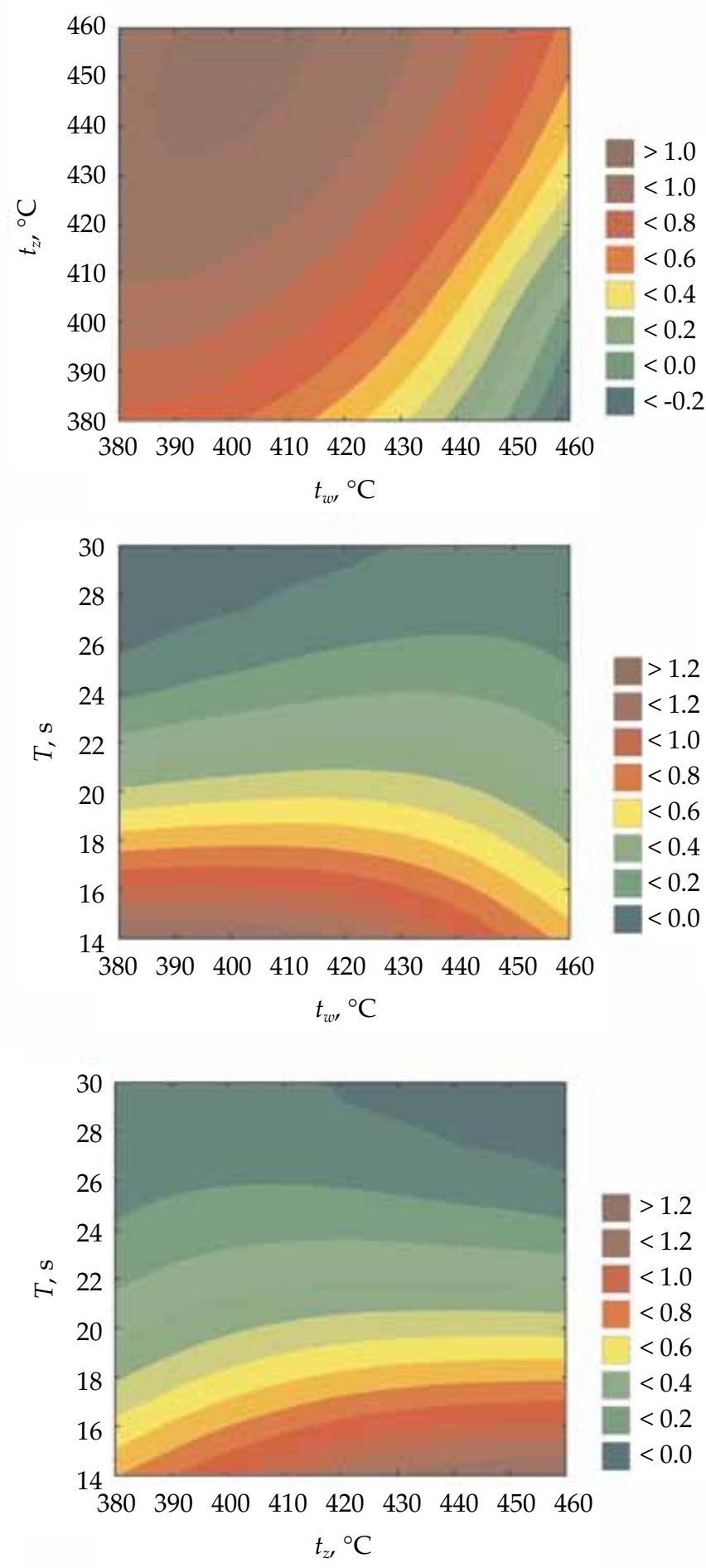

Fig. 5. Total utility of finished parts produced without pre-blow versus internal zone temperature $\left(t_{w}\right)$ and external zone temperature $\left(t_{z}\right)$ of the heater and heating time $(T)$

The empirical models of the wall thickness variations for finished parts produced with pre-blow, were obtained as Eq. (4) and (5).

\footnotetext{
$\Delta g=-6.20326+0.0246214 t_{w}-0.00002765 t_{w}{ }^{2}-$ $0.005889 t_{z}-0.0000016 t_{z}^{2}+0.190131 \mathrm{~T}-$

$0.0007577 T^{2}+0.000018 t_{z} t_{w}-0.0003719 t_{w} T+$ $0.0000094 t_{z} T$
} 


\section{Profiles of approximated factors and utility}
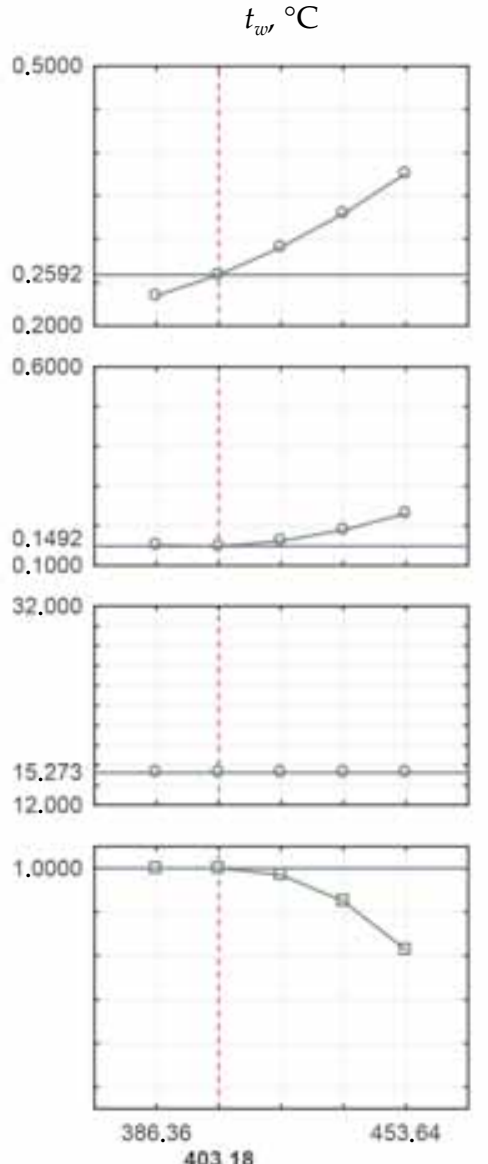

$t_{z^{\prime}}{ }^{\circ} \mathrm{C}$

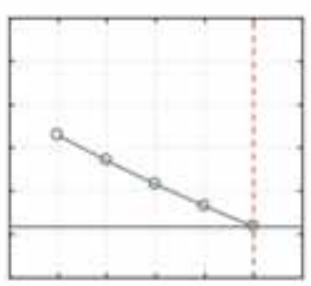

$T, \mathbf{s}$
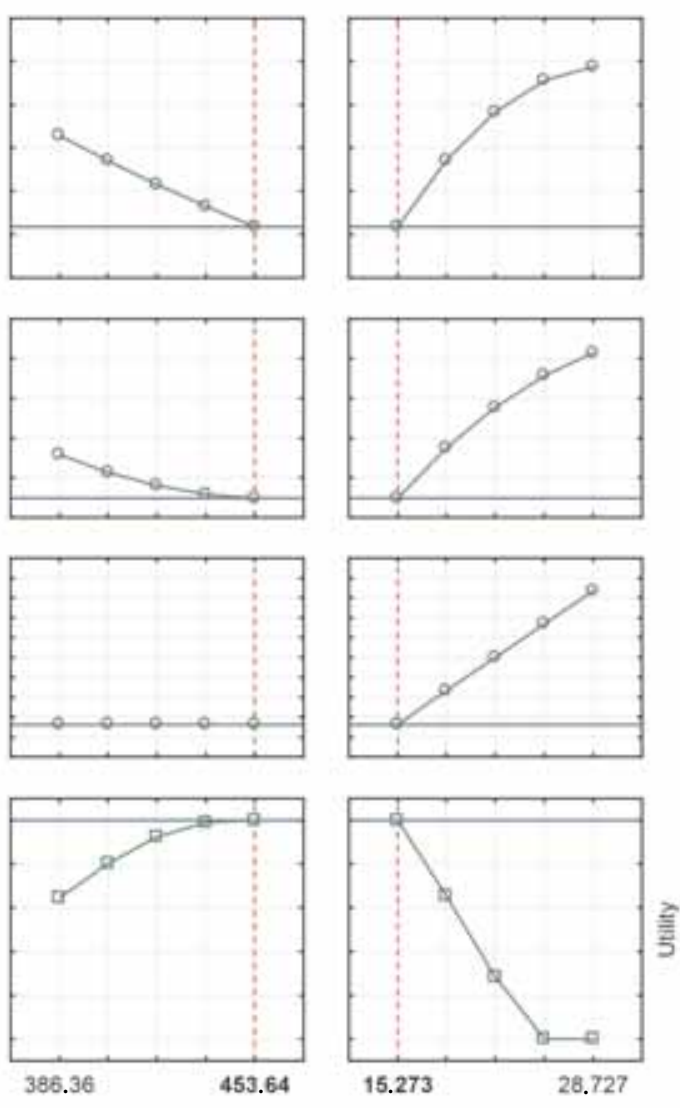

Utility
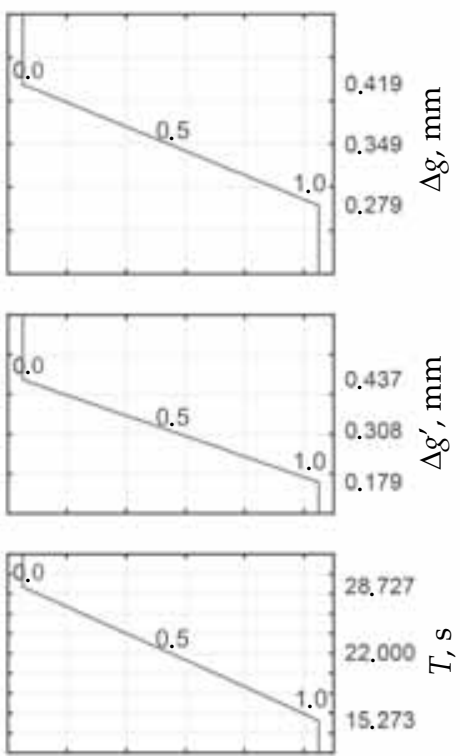

Fig. 6. Profiles of approximated optimized factors and their response utility as determined for finished parts produced without pre-blow; the vertical dotted lines denote the values of independent variables which maximize total utility

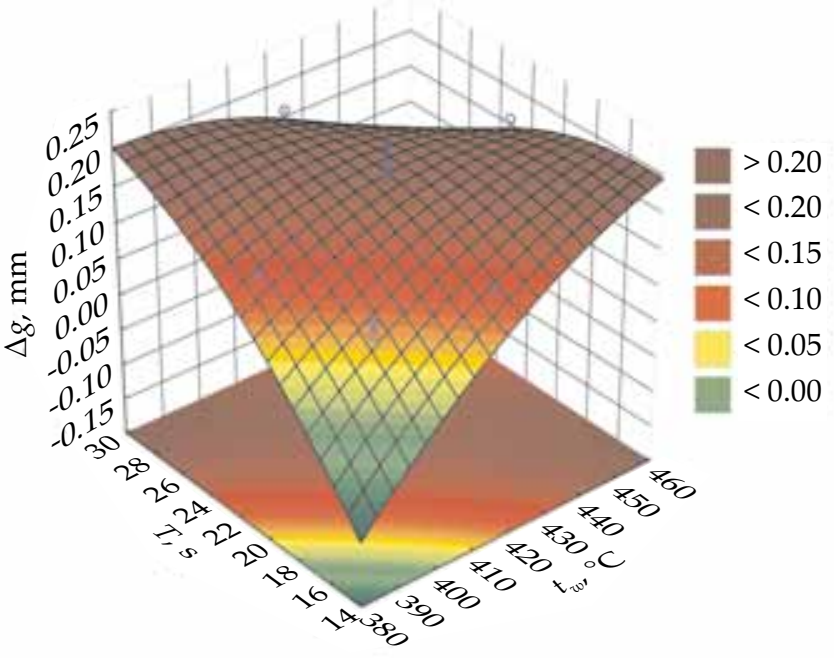

Fig. 7. Wall thickness variations $(\Delta g)$ in the longitudinal section of finished parts produced with pre-blow versus internal zone temperature $\left(t_{w}\right)$ and heating time $(T)$ at $t_{z}=420^{\circ} \mathrm{C}$

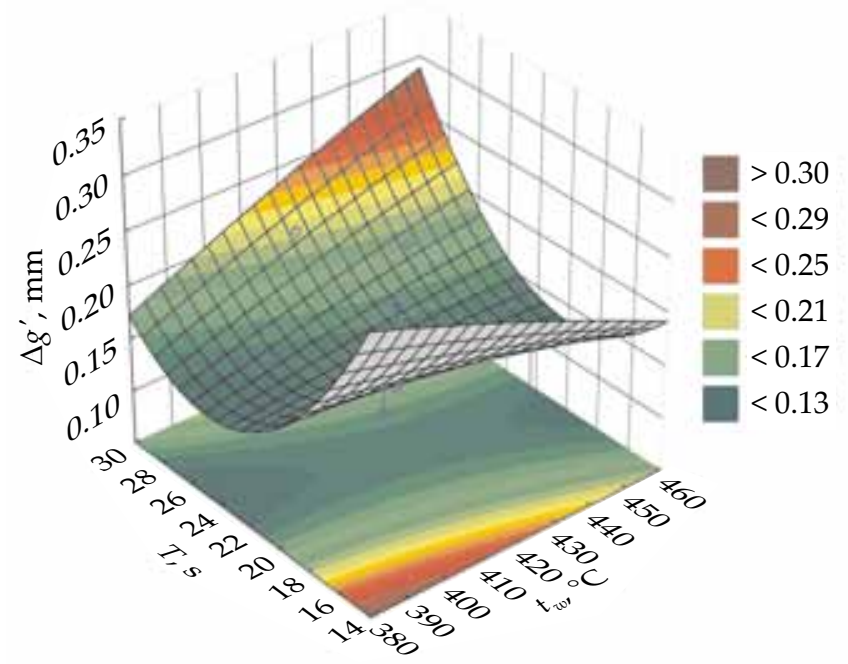

Fig. 8. Wall thickness variations $\left(\Delta g^{\prime}\right)$ in the cross section of finished parts produced with pre-blow versus internal zone temperature $\left(t_{w}\right)$ and heating time $(T)$ at $t_{z}=420^{\circ} \mathrm{C}$ 

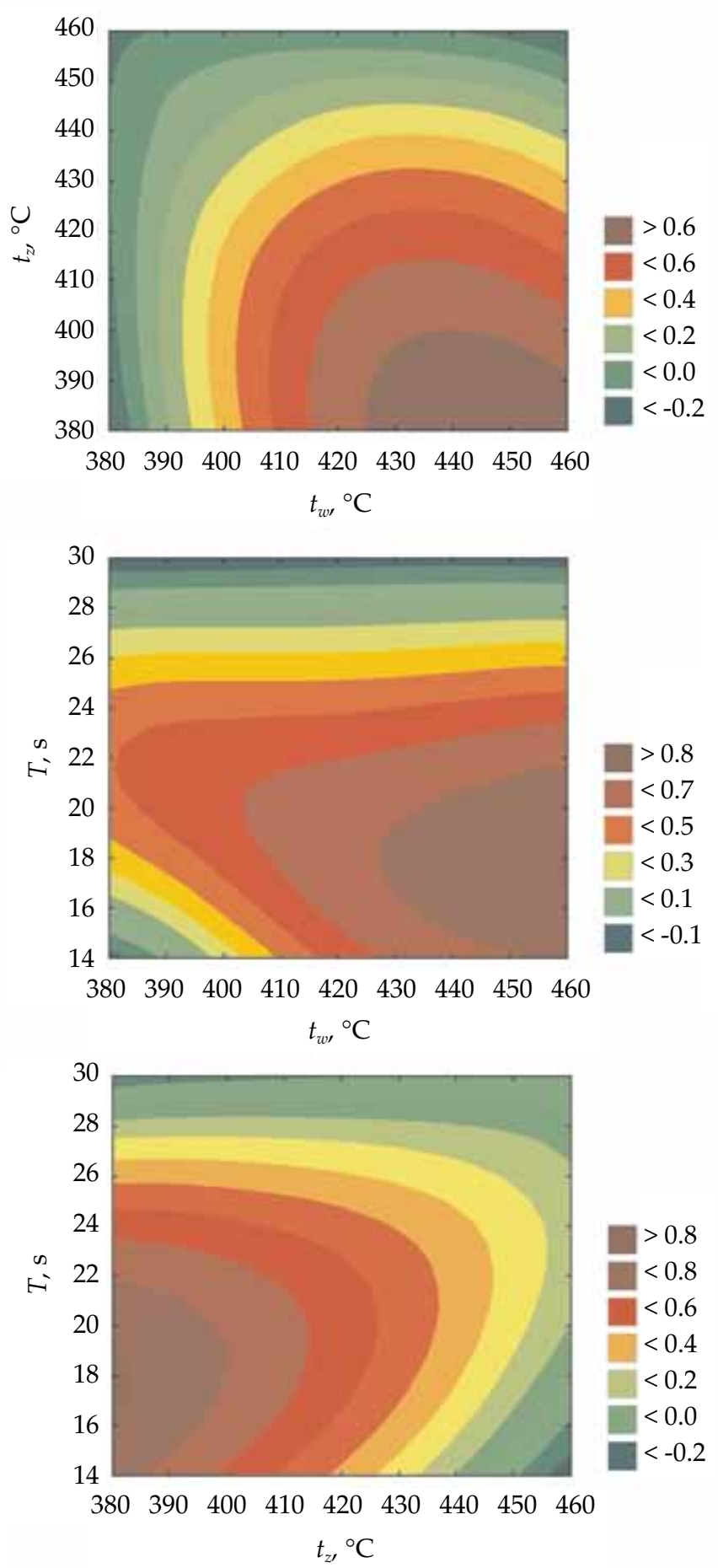

Fig. 9. Total utility of finished parts produced with pre-blow versus temperature in the internal zone $\left(t_{w}\right)$ and external zone $\left(t_{z}\right)$ of the heater and heating time $(T)$

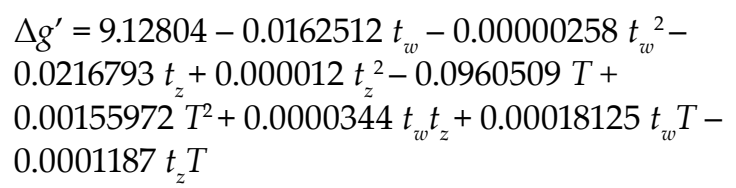

As for the finished parts produced with pre-blow, the Pareto analysis results demonstrate that the variations in wall thickness in their longitudinal section $(\Delta g)$ are significantly affected by the heating time $(T)$ and the temperature in the internal zone of the heater $\left(t_{w}\right)$ as well as by interactions between them. The variations in wall thickness in the cross section $\left(\Delta g^{\prime}\right)$ of the finished parts are only affected by the heating time $(T)$.

The relationships between the wall thickness variations in the longitudinal section $(\Delta g)$ of finished parts produced with pre-blow versus the heating time $(T)$ and temperature in the internal zone of the heater $\left(t_{w}\right)$ are illustrated in Fig. 7. The effect of the above independent factors on the wall thickness variations in the cross section $\left(\Delta g^{\prime}\right)$ of finished parts is shown in Fig. 8 .

The total utility determined for finished parts produced with pre-blow by the spline functions method is illustrated in Fig. 9. As can be observed, the methods used previously were employed to find optimum utility.

Approximation profiles of the optimized factors $(\Delta g$, $\left.\Delta g^{\prime}, T\right)$, one per each input variable, are shown in Fig. 10. They were determined by taking optimum values as current values for other input variable. The figure also shows diagrams presenting total response utility profiles at every input mesh point at optimal values of other factors (three diagrams at the bottom of the figure). The diagrams in a vertical column on the right illustrate the defined linear utility functions.

Determined by browsing through the input variables mesh nodes, the maximum total response utility is equal to 0.76 when the input factors are: $t_{w}=454{ }^{\circ} \mathrm{C}$, $t_{z}=386^{\circ} \mathrm{C}$ and $T=15 \mathrm{~s}$. The region around the optimum value (Fig. 9) is quite extensive, so the deviations of the independent factors from the determined optimum values should not significantly affect the obtained utility. In thermoforming with pre-blow, the application of the determined values of independent factors will enable producing finished parts with the smallest wall thickness variations in both sections at the shortest possible heating time.

\section{CONCLUSIONS}

On the whole, it can be concluded that the proposed method enables not only determination of optimum thermoforming conditions, but it also provides information about interactions between these conditions and their impact on the properties of finished parts and heating time. It should be stressed that the proposed method enables finding an optimum based on a series of characteristics (criteria) at the same time, the list of which can be extended as desired, which is significant in terms of practical applications.

The optimum values of independent factors determined with the assumed optimization criteria differ for thermoforming without pre-blow and thermoforming with pre-blow. It has been found that in order to produce finished parts with the smallest wall thickness variations, low temperatures in the internal zone of the heater and the highest temperatures from the tested range in the external zone of the heater should be applied. With the 


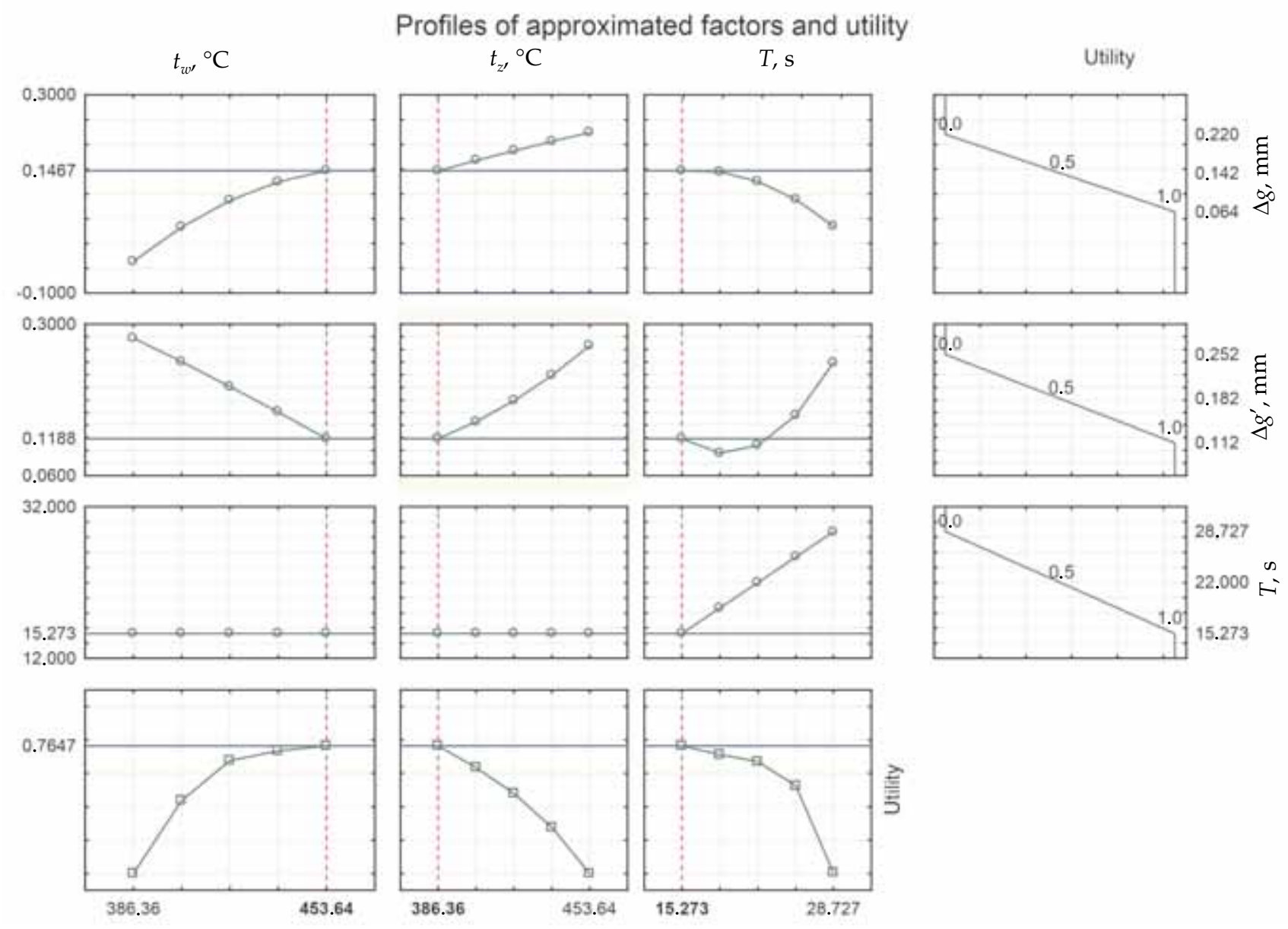

Fig. 10. Profiles of approximated factors subjected to optimization and their response utility determined for finished parts produced with pre-blow; the vertical dotted lines mark the values of independent variables which maximize total utility

application of pre-blow leading to significantly smaller wall thickness variations in finished parts, it is desired to apply, in the tested temperature range, the highest temperatures in the internal zone and the lowest temperatures in the external zone of the heater. This results from significant differences in stretching of particular regions of the finished parts during the two processes. This problem will be discussed in a separate publication.

\section{REFERENCES}

[1] Potente H., Hanhart W., Reski T.: Polymer Engineering and Science 1994, 34, 937.

http://dx.doi.org/10.1002/pen.760341111

[2] Potente H., Schoppner V., Ujma A.: Journal of Polymer Engineering 1997, 17, 153.

http://dx.doi.org/10.1515/POLYENG.1997.17.2.153

[3] Broel-Plater B.: Polimery 1997, 42, 386.

[4] Potente H.: Kunststoffe Plast Europe 1999, 89, 27.

[5] Fernandes C., Pontes A.J., Viana J.C., Gaspar-Cunha A.: Polymer Engineering and Science 2010, 50, 1667.

http://dx.doi.org/10.1002/pen.21652

[6] Fernandes C., Pontes A.J., Viana J.C. et al.: International Polymer Processing 2012, 27, 213. http://dx.doi.org/10.3139/217.2511

[7] Verbraak C.P.J.M., Meijer H.E.H.: Polymer Engineering and Science 1989, $29,479$.

http://dx.doi.org/10.1002/pen.760290708

[8] Stasiek J.: Polimery 1995, 40, 214.

[9] Stasiek J.: Polimery 1997, 42, 14.

[10] Nastaj A., Wilczyński K.: Polimery 2018, 63, 38. http://dx.doi.org/10.14314/polimery.2018.1.6

[11] O'Connor C.P.J., Martina P.J., Sweeney J. et al.: Journal of Materials Processing Technology 2013, 213, 1588. https://doi.org/10.1016/j.jmatprotec.2013.02.001

[12] Throne J.L.: "Technology of Thermoforming", Hanser Publishers, Munich 1996.

[13] Klein P.W.: "Fundamentals of plastic thermoforming. Synthesis lectures on materials engineering", Morgan \& Claypool Publishers 2009.

[14] Throne J.L.: "Understanding thermoforming", Hanser Publishers, Munich 2008.

[15] Schwarzmann P.: “Thermoforming - A Practical Guide", Hanser Publishers, Munich 2001.

[16] Ekşi O., Karabeyoğlu S.S.: Advances in Science and Technology Research Journal 2017, 11, 198. http://dx.doi.org/10.12913/22998624/71147

[17] Klepka T.: Polimery 2002, 47, 649. 
[18] Klepka T., Jeziorska R., Szadkowska A.: Przemyst Chemiczny 2015, 94, 1352.

http://dx.doi.org/10.15199/62.2015.8.21

[19] Jachowicz T., Garbacz T., Tor-Swiatek A. et al.: International Journal of Polymer Analysis and Characterization 2015, 20, 307.

http://dx.doi.org/10.1080/1023666X.2015.1016788

[20] Żenkiewicz M., Richert J.: Polimery 2009, 54, 299.

[21] Żenkiewicz M., Szach A.: Polimery 2010, 55, 337.

[22] Hopmann Ch., Martens J.: Kunststoffe 2015, 8, 67.

[23] Van Mieghem B., Desplentere F., Van Bael A. et al.: eXPRESS Polymer Letters 2015, 9, 119. http://dx.doi.org/10.3144/expresspolymlett.2015.13

[24] Lee R.E., Guo Y., Tamber H. et al.: Industrial and Engineering Chemistry Research 2016, 55, 560. http://dx.doi.org/10.1021/acs.iecr.5b03473

[25] Hosseini H., Berdyshev B.V., Mehrabani-Zeinabad A.: Polymer Engineering and Science 2009, 49, 240. http://dx.doi.org/10.1002/pen.21245

[26] Raurí McCool R., Martin P.J.: Polymer Engineering and Science 2010, 50, 1923. http://dx.doi.org/10.1002/pen.21718

[27] Erdogan E.S.: Journal of Mechanical Engineering 2014, 60, 195. http://dx.doi.org/10.5545/sv-jme.2013.1486

[28] Min S.C., Zhang H.Q., Yang H.J.: Journal of Food Processing and Preservation 2011, 35, 758. http://dx.doi.org/10.1111/j.1745-4549.2011.00526.x

[29] Mohan T.P., Kanny K.: International Journal of Material Forming 2014, 8, 401. http://dx.doi.org/10.1007/s12289-014-1183-x
[30] Engelmann S.: "Advanced Thermoforming: Methods, Machines and Materials, Applications and Automation", John Wiley \& Sons, Chichester, UK, 2012.

[31] Sykutera D., Pepliński K.: Inżynieria i Aparatura Chemiczna 2011, 50, 73.

[32] Karabeyoglu S.S., Ekşi O., Erdoğan S.: Advances in Science and Technology Research Journal 2017, 11, 139. http://dx.doi.org/10.12913/22998624/71148

[33] Tangpornprasert P., Virulsri C.: Applied Mechanics and Materials 2015, 751, 159.

http://dx.doi.org/10.4028/www.scientific.net/ AMM.751.159

[34] Kojima I., Takeda T., Nakajima K. et al.: Dental Traumatology 2015, 31, 103. http://dx.doi.org/10.1111/edt.12145

[35] Azdast T., Doniavi A., Ahmadi S.R. et al.: International Journal of Advanced Manufacturing Technologies 2013, 64, 113. http://dx.doi.org/10.1007/s00170-012-4007-5

[36] Myers R.H., Montgomery D.C., Anderson-Cook Ch.M.: "Response Surface Methodology: Process and Product Optimization Using Designed Experiments", John Wiley and Sons, New York 2009.

[37] Montgomery D.C.: "Design and Analysis of Experiments", 7th. Ed., John Wiley \& Sons 2009.

[38] Technical documentation of the test stand for stretching PEX B-3F. http://www.pex.biz.pl/oferta-podglad.php?id=5 (access date 12.01.2018)

Received 20 II 2018 